\title{
How Carl Schmitt's Theory Contributes to Liberalism: The Domestic Application of the Concept of the Political and the Possibility of Realistic Liberalism
}

\author{
Zhengguo Qin ${ }^{1, a,{ }^{*}, \dagger}$, Xuezhu Wang ${ }^{2, \mathrm{~b}, *, \dagger}$, Zhaoyuan Yang ${ }^{3, \mathrm{c},{ }^{*}, \dagger}$, Zhiwei Zhou ${ }^{4, \mathrm{~d}, *, \dagger}$ \\ ${ }^{1}$ College of the Holy Cross, Worcester, 01601, The People's Republic of China \\ ${ }^{2}$ Columbia University in the City of New York, New York, 10041 NY 212, The People's Republic of China \\ ${ }^{3}$ The Chinese University of Hong Kong, Hong Kong, 999077, The People's Republic of China, \\ ${ }^{4}$ Central South University, Changsha, 410000, The People's Republic of China \\ *Corresponding authors.Email: ${ }^{a}$ zqin25@g.holycross.edu, ${ }^{b} x w 2764 @$ columbia.edu, ${ }^{c} 1155122983 @$ link.cuhk.edu.hk, \\ dfranciszhou@csu.edu.cn
}

†These authors contributed equally.

\begin{abstract}
Carl Schmitt, the controversial German political thinker, deeply influenced the 20th century with his critique of liberalism. Many scholars have developed his ideas, using them as a powerful theoretical resource for conservatism. This article seeks to introduce his realistic theories to domestic politics in democratic countries after making necessary developments to Schmitt's theory and explore the underlying tendency of liberalism in his theory. We will first reanalyze the concepts of politics, enemy, and war to propose and demonstrate that the essence of an enemy is the existence of a hostile status. The application of Schmitt's theory to domestic politics presents the need to introduce a realistic perspective to liberalism. Considering the escalating antagonism as evidenced by recent political science research within democracies, realistic liberalism may effectively recognize the threats that are negated by liberals and could warn us of authoritarianism and the encroachments on political rights.
\end{abstract}

Keywords: Carl Schmitt, realism, liberalism, domestic politics.

\section{INTRODUCTION: SCHMITT, REALISM, AND LIBERALISM}

In the world of liberalism, Carl Schmitt is sometimes marginalized and demonized. However, increasing manifestations of political antagonism caused by racialized conflicts, social inequality, and so on in the domestic politics of democracies are reminiscent of his realistic thought. Actually, "a spectre is haunting the western world - the spectre of Carl Schmitt's realism." As one of the most famous political thinkers in the 20th century, Schmitt's thoughts had a vital influence on the development of conservatism. In Schmitt's representative book, the Concept of the Political, whose topics will be the main subject of our discussion in this essay, he analyzes the concepts of the political, war, and enemy. He describes a world in which politics can never be abolished. This essay seeks to show that Carl Schmitt's theory could serve as a salutary supplement to liberalism when applied to domestic politics. Still, first, we need to develop his theory to make this application possible. As a result of certain paradoxes and vagueness within his conceptualization of the political, war, and enemy, Schmitt fails to apply his theory to domestic politics. In response to these problems, this article will first reanalyze the concepts of politics, enemy, and war and demonstrate how politics is dependent on other domains based on Schmitt's core ideas. Second, our essay will propose and demonstrate that the essence of an enemy is the existence of a hostile status that can be reduced to other domains; war, typically seen as violence elevated to exceptional levels, will be used as an example to illustrate this point. Finally, after applying the above development of Schmitt's theory, our essay will explain why this application provides liberalism with a valuable perspective of realism.

Schmitt, whose seminal work The Concept of the Political became canonical for 20th-century 
conservatives, has his reputation partly accredited to his theoretical successor, Leo Strauss. On the one hand, Strauss wrote in support of conservatism in continuity with Schmitt's ideological stance; on the other hand, in his Note on the Concept of the Political, Strauss insightfully points out and opposes how Schmitt is close to liberalism in his critiques of liberalism. In other words, it seems that Schmitt's being as "tolerant as liberals" precluded Schmitt's critiques from being sufficiently effective [1].In his book Carl Schmitt's Critique of Liberalism: Against Politics as Technology, John McCormic makes a comprehensive analysis of Schmittian critique of liberalism [2]. His analysis refuses to simply defend or refute Schmitt. Instead, he believes that Schmitt stands with liberals and tries to save liberalism from the pitfall of modernity. This essay shares a similar interest with McCormic. Still, we will emphasize applying Schmitt's theory to modern democracies and concern ourselves more with some urgent problems of modern democracies. German legal scholar, Ernst-Wolfgang Bockenforde clarifies Schmitt's concept of the political and then discusses the application of Schmitt's theory to domestic politics, whose demonstrations and conclusions are comparable to those of this essay [3]. However, this essay will analyze in detail the political, war, and enemy notions, which are proved to be logical in close relationships. Moreover, we also notice the liberal value of this application in democracies. In this essay, we will explore the presence of liberalism in Schmitt's realist theories; we will also explore how the possibility of realistic liberalism serves as beneficial supplements to liberalism.

The conclusion of recent research from political scientists has shown the necessity of a realistic interpretation of liberalism. Finkel et al.'s research has proven that political polarization and sectarianism give rise to hostile actions amongst opposing partisans [4], which may bring about harmful consequences to and cannot be well explained by liberalism. Thus, it is necessary to grant intellectual value to what seems like the intersection of modern ideologies and explore the pragmatic possibility and significance of realistic liberalism.

\section{THE DEVELOPMENT OF SCHMITT'S THEORY}

To apply Schmitt's theory to domestic politics, it is necessary to solve the paradoxes and vagueness within his theory and develop it further. Bockenforde maintains that two widespread misunderstandings to the Concept of the Political preclude us from applying Schmitt's theory to domestic politics. First, the application of friend-and-enemy distinction seems to turn into a situation where thwarts any peaceful possibility. The second misunderstanding considers Schmitt's work as a normative theory that indicates that politics' purpose and substance are friend-and-enemy distinction and militant conflict. Bockenforde argues that we can apply the concept of the political to domestic politics only after we properly dissolve those understandings. Meanwhile, domestic politics plays a powerful role in modern democracies. At times, we see the prevalence of partisan conflicts that are sometimes elevated to a level of intensity that hampers the normal functions of government and brings about the encroachment of political rights. Schmitt fails to apply his theory to domestic politics because he does not fully explore the purpose and substance of politics and the essence of the enemy. It is to be noted that we use the Aristotelian definition of the essence, i.e., the indispensable characteristic that defines what the enemy is to be. This essay believes that certain paradoxes and vagueness cause those misunderstandings in Schmitt's work. And those misunderstandings will be dissolved when we develop further on the purpose and substance of politics and the essence of the enemy.

First, there is an apparent paradox within his characterization of the political. Carl Schmitt asserts that the political can exist theoretically and practically without simultaneously drawing upon other domains [5]. However, this assertion contradicts his later arguments:

(1) "The political can derive its energy from the most varied human endeavors, from the religious, economic, moral, and other antitheses. It does not describe its own substance, but only the intensity...[that] can effect at different times different coalitions and separations." [5]

(2) "Politics is the most intense and extreme antagonism" [5]

According to Schmitt's description, he believes that politics has no substance of its own; rather, it merely describes the intensity of antagonism in other domains. Thus, the antagonism as to the substance of the political is derived from other domains. As a result, the political cannot exist singularly in theory or in practice. (Bockenforde has a similar conclusion on the relationship between the political and other domains in his article) [3].

The substance of the political is vital because it constructs the content of the purpose of the political. As a category that involves grouping and antithesis, the fundamental purpose of the political should be to eliminate its antithesis, which is the same as the purposes of other domains. But in other domains, the elimination of the other side is conducted in different approaches and has different targets, which are closely related to their substance. For example, the goal of commerce can be to exclude other possible competitors by monopolizing the market; the goal of religion can be 
to expand the number of believers; the goal of morality can be to promote values and to make certain ideas become mainstream. Schmitt does not clearly describe the purpose of the political; he only denies the war as the purpose of the political [5]. If the elimination of the enemy is not necessarily conducted through war, it seems that the purpose of politics can only be constructed by its substance derived from other domains. If the specific content of the purpose of the political is to eliminate the enemy, what is the essence of the enemy? And how could we conduct this elimination? These two issues cannot be ignored. If there is no clear answer, the concept of politics cannot be well described.

This article uses the example of war to answer. According to Schmitt, war is "the existential negation of enemy" that involves "physical killing" [5]. If war is not the purpose of the political, it must serve the purpose of the political. The purpose of the political determines and restrains the extent of war. Meanwhile, Schmitt also mentions that within the classic laws of war, a peace treaty is attainable and even constitutes the normal, selfevident end of the war [6]. When the purpose of the political is, or at least partly, achieved, the war ends, permanently or temporarily. Therefore, we must analyze the ending of this collective existential negation. JeanJacques Rousseau claims that no one has further right over the enemy's lives as soon as they lay their arms down and surrender, ceasing to be enemies or instruments of the enemy [7]. However, enemies ceasing to be enemies is not simply because they drop their arms, but also because we force them to accept the conditions that will change their status as our enemies. Those enemies are enemies not because they can attack us violently but because they represent certain antagonism in other domains. Even those who cannot wage war can be enemies, too. For instance, the Nazis considered Jews their political enemies, and they conducted genocide in concentration camps while receiving little resistance. Under such a circumstance, the negation of enemies' existence is not a war anymore, but a massacre.

Therefore, the purpose of politics is to eliminate hostility. The enemy should be understood as the existence of a hostile status reducible to conflicts in domains such as religion, economics, and so on. Suppose the cause of the war is a dispute over religious beliefs. In that case, when one party is forced to convert to the other's beliefs, the hostility will be eliminated, subsequently ending the war. Suppose there is a war between two nations over economic interests when the two nations reach a settlement agreement on the disputed issue. In that case, the state of hostility between the two nations will be eliminated. As is evident, we do not have to conduct the existential negation of the enemy to reach the purpose of the political, as long as we can eliminate the hostile status of the enemy by other means.

\section{APPLICATION OF SCHMITT'S THEORY TO DOMESTIC POLITICS IN DEMOCRACIES AND ITS SIGNIFICANCE}

Schmitt's theory could be better applied to domestic politics after we make the above development and adjustments. For Schmitt, he points out the realistic situation where enemies are and will be perpetually present. He also cautions people against the ambitious, liberal attempts to dissolve this ever-present existence. After we develop his theory and apply it to domestic politics, Schmitt's concern is still appropriate. Some politicians have tried or are trying to dissolve the existence of the partisan enemy, and the consequence of this dissolution is no less threatening and destructive than the liberals' negation of friend and enemy that Schmitt criticizes. However, the recognition of partisan enemies is inherently a liberal thought, and therefore the constitutional respect. From this application, it can be inferred that acknowledging the grouping of partisan enemies and friends is significant, and negating it is threatening.

\subsection{Partisan Politics and Partisan Enemies}

Based on the development of Schmitt's theoretical framework, partisan politics can be analysed. It presupposes a grouping of partisan friends and enemies and a possibility of the existential negation of partisan enemies to exterminate the enemy's hostile status. In the two-party system, each party considers the other as a clear and aggressive rival. While in the multi-party system, party coalitions are often established against other coalitions or other powerful parties. Parties in the same coalition usually do not share identical policy preferences and political values. Still, they are partisan friends because they fight against their common partisan enemies and are determined to prevent their enemies from taking over power.

Thus, the hostile status of partisan enemies is only reducible to partisan reasons, which is the claim of sovereignty or the decisive power. The antithesis of one's claim of sovereignty is another's claim of sovereignty. Partisans claim their sovereignty and negate their partisan enemies' claims of sovereignty. However, the antithesis becomes political only when the antagonism escalates so intensely that it presupposes a possibility of a civil war. Schmitt's theory of decisionism can support this analysis of the hostile status of partisan enemies. He asserts that every party wants the sovereignty that has the decisive power in the controversies of general goods pursued by different parties [8]. Compared with a non-political situation, this antagonism also exists in a political discussion in one's 
community or university. Politicians have two different ways to claim sovereignty. First, they can certainly wage a civil war and take sovereignty. Second, they can win sovereignty by a legitimized election. Civil war can be regulated by constitutional norms or agreements, just like how international laws or agreements regulate the risk of war between states.

\subsection{The Threats of Negating the Partisan Status}

The political is a war of existence and elimination, as Schmitt implies. And it is also the same for domestic politics, although collective violence in domestic politics is stringently constrained. In domestic politics, partisans eliminate their partisan enemies' hostile status by negating their claim to sovereignty. But the hostile status will not be eliminated even when one party takes the sovereignty since their partisan enemies still can claim sovereignty by those two ways above. Hence, partisans aim to reduce the possibility that their enemies can take over sovereignty and finally eliminate this possibility. The elimination of partisan status usually happens in monarchies, authoritarian states, and some ancient states.

Historically, Adolf Hitler and Joseph Stalin prosecuted their dissenters and physically killed them if necessary, which effectively eliminated the possibility of their dissenters' claim to sovereignty. In other milder situations, the government could restrain or deprive the political rights of certain individuals to reduce this possibility. Additionally, in the work of Thucydides, the Corcyrean democrats planned to eliminate the threats from the oligarchs once and for all, so they executed all of them cruelly, and the civil war came to a tragic end [9].

In a more recent situation, attempts to negate enemies' partisan status are conducted in various and covert ways, but they are no less dangerous to democracy. In modern democratic countries, like the United States, partisan antagonism is regulated by orchestrated constitutional norms. However, according to Schmitt's realist theory, partisans have strong incentives to keep their enemies out of the political arena by attacking enemies' hostile status, i.e., the political rights to claim (or that are essential to claim) sovereignty. Those attacks on constitutional norms are harmful to democracy, and it is difficult to defend democracy from those attacks when partisan antagonism becomes fierce.

The latest research conducted by Finkel et al. [4] on political science has proved this unfortunate connection between partisan antagonism and undemocratic behaviours in the US. Their finding suggests that "most voters are partisan first and democrats only second". Partisans would support the politicians who pursue party interests and electoral victories by damaging basic democratic principles like electoral fairness, checks, and balances, as well as civil liberties [10]. The violations of democratic principles are serious attacks on partisan enemies' political rights, which effectively restrain the hostile status of enemies. Such infringements of democratic principles can be frequently attributed to political polarization rooted within partisan antagonism. Under highly polarized political situations, voters tend to conduct acts of "othering, aversion, and moralization" against the opposing partisans [4]. These three ingredients of political "sectarianism" also represent Schmitt's theory of friend and enemy [4]. When partisans derogate their enemies, they likely intend to justify their negation of their enemies' partisan status. The fact that partisans call their enemies the "enemy of the people" echoes with those liberals referring to their enemies as the "enemy of mankind" in Schmitt's work, which is a tactic that serves to procedurally justify the waging of inhuman wars against those enemies. As a consequence of eliminating opposition parties, partisans who devalue democratic norms and derogate their enemies would push the country into authoritarianism.

\subsection{A Schmittian Warning}

As a result, it is obvious that if partisans are determined to eliminate the existence of enemies, they would restrain or deprive the political rights of individuals and even kill their enemies if necessary, which is unjust, gruesome, and unacceptable. Schmitt warns us that if liberals try to eliminate the grouping of friends and enemies, horrible and destructive wars would be started [5], and the total domination of capitalism would be established [5]. Here, the new development of his concepts also warns us: if partisans try to eliminate partisan grouping and establish their indubitable and absolute sovereignty, it would be catastrophic for basic political rights and finally lead to authoritarianism. And this drastically antagonistic situation could be described as a "state of nature" in domestic politics. All political partisans drastically fight against each other, and they would secure their position by any possible means till they see no other power great enough to endanger them [11].

Meanwhile, the reinterpretation of Schmitt's theory presents certain liberal values that are fundamental for modern democracies in a realistic way; thus, it supplements liberalism with a realistic perspective. According to this interpretation, partisans are supposed to recognize the situation where the existence of partisan enemies is permanent and control their desire to eliminate their enemies. They should pursue their political purposes within a constitutional system that endows and protects basic political rights, including freedom of speech, voting rights, etc., enabling all participants to possess their partisan statuses. They 
should abide by basic democratic norms, including electoral fairness, check and balance, civil liberties, etc. Especially when one party takes over the sovereignty, they have strong incentives to encroach on their enemies' political rights. Therefore, it is of great importance to supervise and restrict the authorities from taking any harmful actions.

\section{THE POSSIBILITY OF REALISTIC LIBERALISM}

Schmitt's underlying tendency for liberalism was probably first articulated by Leo Strauss in his critical work Note on the Concept of the Political. As Strauss said, Schmitt "undertakes the critique of liberalism in a liberal world" and is inevitably "restrained by the still unvanquished 'systematics of liberal thought' " [1]. For Strauss, he asserts that those liberal legacies are the shortcomings of Schmitt's theory and makes it more cogent in criticizing liberalism by further clarifications. While our essay carefully examines the liberal potential within Schmitt's ideas, we apply his theory to the sphere of domestic politics after making several adjustments.

By applying Schmitt's theory to domestic politics, a realistic perspective is provided for liberals. We see how Schmitt's theory is conducive to understanding and coping with the crisis of liberalism. According to Schmitt's realism, liberals always overlook or even reject insidious political threats by not recognizing the ever-present grouping of friends and enemies. Liberalism fails to explain why social conflicts like racialized conflicts, political polarization, and social inequality can be so intensified, nor does liberalism explain why people tend to be hostile to their so-called compatriots in extraordinary cases such as a civil war and persecution. In contrast, realistic liberals would understand conflicts as a consequence of the grouping and be vigilant about the unavoidable intention of elimination of the hostile status of the enemy. The intention of eliminating hostility might result in serious encroachments on political rights and even lead to a civil war. Thus, a realistic liberal would pay attention to the complexity of various forms of partisan antagonisms derived from different social domains and would alert people of the destructive intentions or actions of elimination motivated by said antagonisms.

Last but not least, it should be emphasized that realistic liberalism is liberalism, not only because it defends liberalism from the possibility of encroachments of political rights, authoritarianism, and even a civil war, but also because it shares and advocates the key values of liberalism, like the respect for individuality, the rule of law that regulates antagonism, and the constitutionalism that protects individuals' rights.

\section{CONCLUSION}

This essay develops Carl Schmitt's theory and applies it to domestic politics in democracies after further developing his theory. After this application, it can be inferred that how Schmitt's theory is conducive to understanding and coping with the crisis of liberalism. We hope the realistic perspective of Schmitt could serve as a supplement to contemporary liberalism. Although the idea of realistic liberalism still awaits further development, the new perspective that realistic liberalism provides has shown its theoretical and practical potential in understanding the crisis of liberalism. We shall not be evasive in the world where enemies exist, living in an illusion of harmony, and liberalism could also be constructed based on recognition of the enemy.

\section{REFERENCES}

[1] Strauss, L and Schmitt, C. "The Hidden Dialogue". Carl Schmitt and Leo Strauss, Chicago: University of Chicago Press, 1995, p. 119, p. 117. https://doi.org/10.7208/9780226221755-005

[2] McCormick, J. (1997). Carl Schmitt's Critique of Liberalism: Against Politics as Technology (Modern European Philosophy). Cambridge: Cambridge University Press. https://doi:10.1017/CBO9780511608988

[3] Böckenförde, E. (1997). The Concept of the Political: A Key to Understanding Carl Schmitt's Constitutional Theory. In D. Dyzenhaus (Eds.), Law as Politics: Carl Schmitt's Critique of Liberalism (pp.37-55). Duke University Press.

[4] Finkel, E. J., Bail, C. A., Cikara, M., Ditto, P. H., Iyengar, S., Klar, S., Mason, L., McGrath, M. C., Nyhan, B., Rand, D. G., Skitka, L. J., Tucker, J. A., Van Bavel, J. J., Wang, C. S., \& Druckman, J. N. (2020). Political sectarianism in America. Science, 370(6516), p. 533. https://doi.org/10.1126/science.abe1715

[5] Schmitt, C. The Concept of the Political. Translated by George Schwab, Chicago: The University of Chicago Press, 2007, pp. 26-27, p. 38 , p. 29, p. 34, p. 33, p. 36, pp. 71-72.

[6] Schmitt, C. Theory of the Partisan: Intermediate Commentary on the Concept of the Political. Translated by G. L. Ulmen, New York: Telos Press Publishing, 2007, p. 9.

[7] Rousseau, J. The Social Contract and The First and Second Discourses. Edited by Susan Dunn, New Haven and London: Yale University Press, 2002, p.161. 
[8] Schmitt, C (2005). Political Theology (G. Schwab,

Trans.) The University of Chicago Press, (Original work published 1922) p.9.

[9] Thucydides. On Justice, Power, and Human Nature: Selections from The History of the Peloponnesian War. Edited and Translated by Paul Woodruff, Indianapolis: Hackett Publishing Company, 1993.

[10] Graham, M., \& Svolik, M. Democracy in America? Partisanship, Polarization, and the Robustness of Support for Democracy in the United States. American Political Science Review, 114(2), 392409. https://doi:10.1017/S0003055420000052

[11] Hobbes, T. Leviathan. Edited by J. C. A. Gaskin, Oxford and New York: Oxford University Press, 1998, p.83. 